\title{
Waiting for Barcelona: A Voice from the Past Century
}

We believe that, in the future, psychosomatic dermatology, psychodermatology and psychocutaneous medicine will disappear together with many other terms and landmarks of the last century. All physicians and all patients will be convinced that the body-mind relationship is constant, essential and, more or less, active and operant in the onset, course and disappearance of all skin disease (and non-skin disease) and all body phenomena, superficial and not. The term/terms that will remain, prophetically preferred when we baptized our society (ESDaP), dermatology and psychiatry, refer to two branches of medicine with a single anatomic base, structurally united in the embryogenesis (and then divided) of the project MAN, cannot ever forget each other: even and above all in the two fundamental fields of research and clinical practice.

It is on the skin, this visible organ, similar to the earth's surface, with its mucosal caverns, that the easiest-to-read messages are designed (easiest-to-read in clinically perceptive, common sense and research points of view), messages from the physiology and pathology of the emotions, stress, and deep psychic conflicts. On this slate one will be able to read, ever more comprehensibly, the phenomena of specific response to psycho-neuro-endocrino-immunologic stimuli. It offers the possibility for diagnosing skin affections that present a basis of more or less high incidence of psychoemotional factors, the dermatological conditions that provoke more or less easily somatopsychic rebound - mental troubles -, and, finally, those psychiatric syndromes with dermatological expression. The latter are mental diseases that the patient often obligates the dermatologist to take into consideration first hand, without right away involving the feared appropriate expert, the psychiatrist.

These and other epistemological aspects were presented in our Commentary in the first issue of this Journal at the beginning of the year 2000, in this journal that younger, more active colleagues have made a reality, taking up the baton of our infinite relay-race. The original articles and case reports presented in this issue are an example of continued keen interest, strong endeavor and sense of responsibility.

In Barcelona, at the foot of the Columbus column facing the immense sea, spring with all its signs and promise of renaissance will help us, POINTING THE WAY of psychosomatic dermatology to a new world of implicit psychosomatic, global, mindbody medicine.

Emiliano Panconesi, Florence

President, European Society of Dermatology and Psychiatry

\begin{tabular}{ll}
\hline KARGER & ( ) 2001 S. Karger GmbH, Freiburg \\
$\begin{array}{l}\text { Fax }+497614520714 \\
\begin{array}{l}\text { E-mail Information@Karger.de } \\
\text { www.karger.com }\end{array}\end{array}$ & $\begin{array}{l}\text { Accessible online at: } \\
\text { www.karger.com/journals/dps }\end{array}$
\end{tabular}

